\title{
ECLETICA
}

www.scielo.br/eq

Volume 29, número 1, 2004

\section{Thermoanalytical study of purine derivatives compounds}

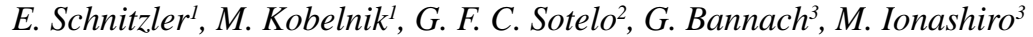 \\ ${ }^{1}$ Departamento de Química - UEPG - CEP 84030-000 - Ponta Grossa - PR - Brasil \\ ${ }^{2}$ Departamento de Engenharia de Materiais - UEPG - CEP 84030-000 - Ponta Grossa - PR - Brasil \\ ${ }^{3}$ Instituto de Química - UNESP - CEP 14801-970 - Araraquara - SP - Brasil
}

\begin{abstract}
Thermal methods of analysis are now used in a very large range of scientific investigations. In this work simultaneous thermogravimetry-differential thermal analysis (TG-DTA), X-Ray powder diffractometry and infrared spectroscopy were used to study the derivative compounds of purine, i. e. aminophylline, theophylline, caffeine and uric acid. The results led to informations about the thermal stability and thermal decomposition of these compounds.
\end{abstract}

Keywords: aminophylline; theophylline; caffeine; uric acid; TG; DTA.

\section{Introduction}

Several investigations have been carried out on the application of thermoanalytical techniques for the study of drug substances, excipients and drug substances in dosage forms. Montagut and co-work [1] investigated dipyrone by employing DTA and TG, and examined the possibility of applying TG in quantitative studies. Wendlandt and Collins [2] used DTA and TG as aids in the characterization and identification of commercial non-preescription analgesics. Other investigations of the use of thermoanalytical techniques for the study of drug substances and for applications in routine pharmaceutical analysis and in the pharmaceutical industry have also been described [3-20].

In this paper derivative compounds of purine were investigated by using thermoanalytical techniques (TG, DTA), X-ray diffractometry and infrared spectroscopy.

\section{Experimental}

Caffeine (3,7-dihydro-1,3,7-trimeyhyl1H-purine-2,6-dione); Theophylline (3,7-dihydro-
1,3dimethyl-1H-purine-2,6-dione) and Aminophylline (3,7-dihydro-1,3-dimethyl-1Hpurine-2,6-dione compd. with ethylenediamine) were obtained from Quimidrol LTDA. Uric Acid (7,9-dihydro-1H-purine-2,6,8(1H,3H,9H)-trione) was obtained from Riedel de Haen.

The formula of these compounds are shown in scheme I

TG, DTG and DTA curves were obtained by using a simultaneous SDT 2960 from TA Instruments. The purge gas was nitrogen flow of $100 \mathrm{~mL} \mathrm{~min}^{-1}$, heating of $20^{\circ} \mathrm{C} \mathrm{min}-1$ and with a sample weighing about $6-8 \mathrm{mg}$. Alumina crucible was used for the TG, DTG and DTA studies.

X-ray powder patterns were obtained with a Simens D-500 X-ray diffractometer using $\mathrm{CuK}_{\text {? }}$ radiation $(?=1,544 \AA)$ and setting of $40 \mathrm{kV}$ and $20 \mathrm{~m} \mathrm{~A}$. Infrared spectra for these compounds were run on a spectrophotometer model FTIR8400 Shimadzu, within the $4000-400 \mathrm{~cm}^{-1}$ range. The solid samples were pressed into $\mathrm{KBr}$ pellets.

Fusion of these compounds was determined by using a melting point apparatus model MQAPF301 from Micro Química. 
<smiles></smiles>

Aminophylline<smiles>Cn1c(=O)c2[nH]cnc2n(C)c1=O</smiles>

Theophylline<smiles>Cn1c(=O)c2c(ncn2C)n(C)c1=O</smiles><smiles>O=c1[nH]c(=O)c2[nH]c(=O)[nH]c2[nH]1</smiles>

Uric Acid

Scheme I: Structure of the derivative compounds of purine.

\section{Results and Discussion}

Theophylline

The TG, DTG curves of theophylline are shown in Fig. 1. These curves show that the compound is stable up to $250^{\circ} \mathrm{C}$, and between 250 $375^{\circ} \mathrm{C}$ the mass loss occurs in a single step, without formation of residue.

The DTA curve, Fig. 2, shows an endotherm between 256 and $375^{\circ} \mathrm{C}$ with two peaks at $273^{\circ} \mathrm{C}$ and $350^{\circ} \mathrm{C}$, respectively. The first endothermic peak is due to the fusion of the compound and in agreement with the literature [21]. The second endothermic peak is due to evaporation of the compound and in agreement with the TG curve, where the total mass loss is observed. The evaporation of the compound occurs without decomposition, in compliance with the infrared spectra of theophylline, and solidified sample collected after evaporation, as can be seen in the Fig. 3.

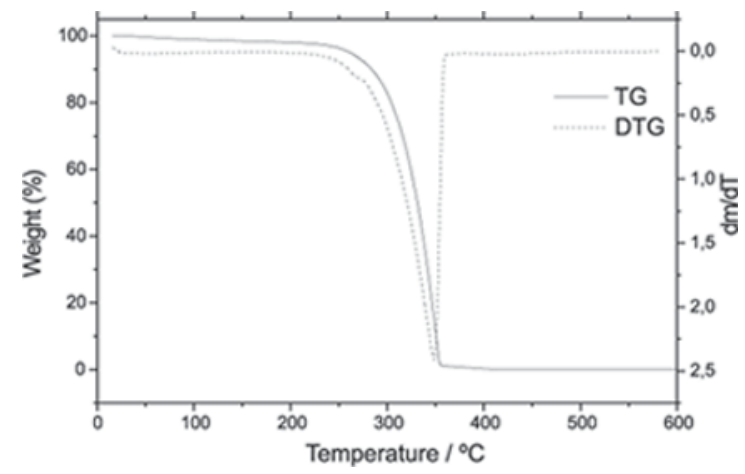

Figure 1- TG and DTG curves of theophylline sample $\left(m_{i}=6.640 \mathrm{mg}\right)$. 


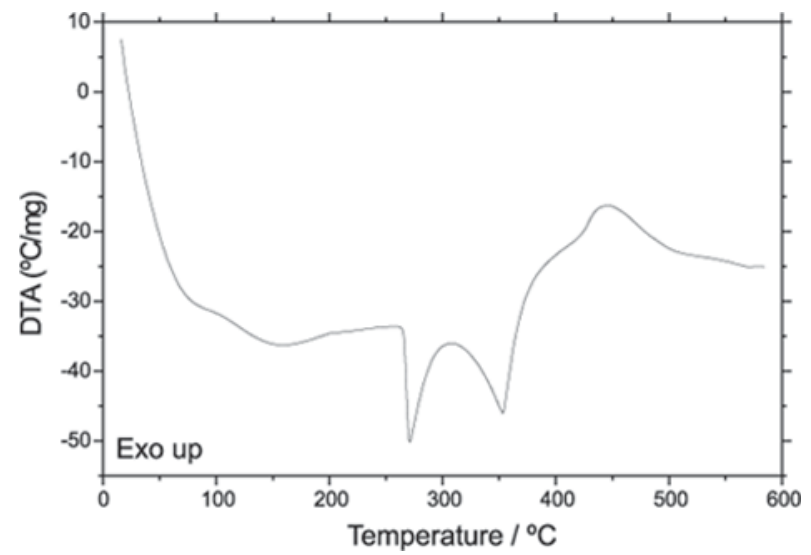

Figure 2 - DTA curve of theophylline sample $\left(\mathrm{m}_{\mathrm{i}}=6.640 \mathrm{mg}\right)$.
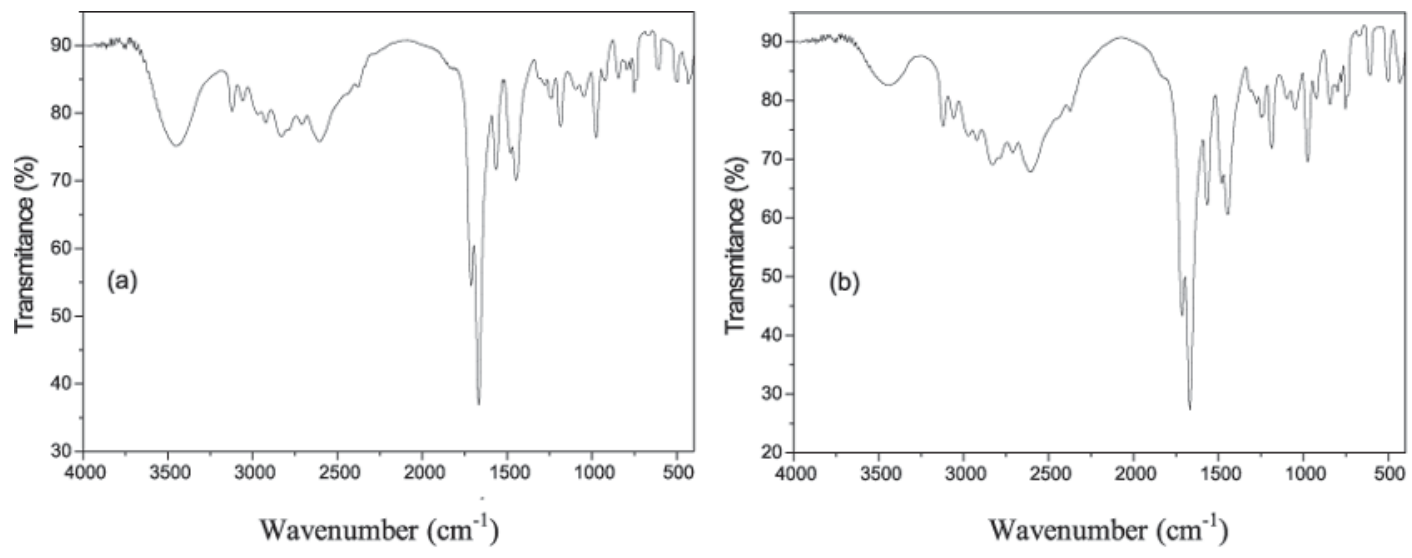

Figure 3 - FTIR spectra of (a) theophylline sample at room temperature (b) sample collected after condensation.

\section{Aminophyline}

The TG and DTG curves of aminophylline are shown in Fig. 4. These curves show that the compound is stable up to $78^{\circ} \mathrm{C}$, and this temperature the TG curve suggests mass loss in two steps, although the DTG curve shows three steps, being the two first as overlapping steps. The mass loss that occurs between 78 and $144^{\circ} \mathrm{C}$ is ascribed to the loss of ethylenediamine (TG=14.41\%); Calcd=14,30\%), with formation of theophylline. The second step that occurs between 238 and $362^{\circ} \mathrm{C}$ with total mass loss is due to evaporation of theophylline.

The DTA curve of aminophylline is shown in Fig. 5. The first endothermic peak at $140^{\circ} \mathrm{C}$ is attributed to elimination of ethyllenediamine and in agreement with the first mass loss of TG curve. The endotherm between 256 and $370^{\circ} \mathrm{C}$ with two peaks at 273 and $330^{\circ} \mathrm{C}$, that show a great similarity with the DTA curve of theophylline, are attributed to fusion and evaporation, respectively. The infrared spectrum of solidified sample collected after evaporation is shown Fig. 6, in agreement with the FTIR spectra of theophylline, Fig. 3. 


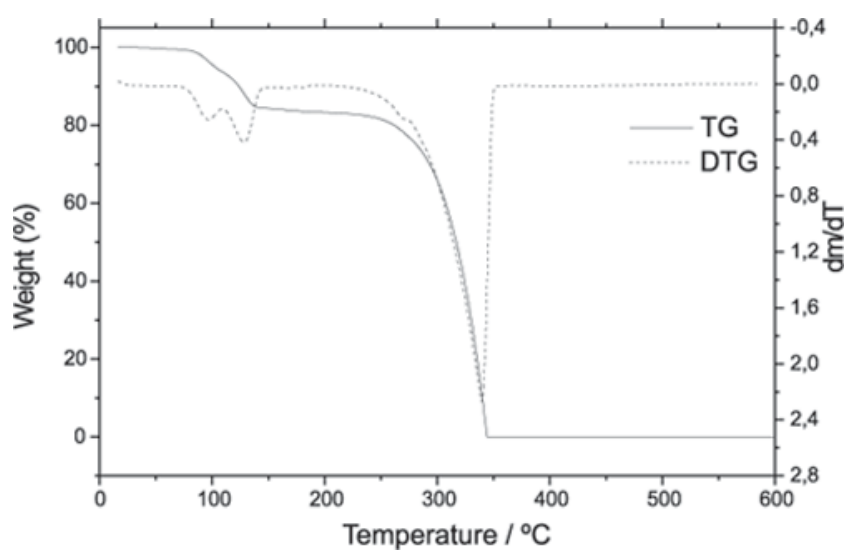

Figure 4 - TG and DTG curves of the aminophylline sample $\left(\mathrm{m}_{\mathrm{i}}=8.607 \mathrm{mg}\right)$.

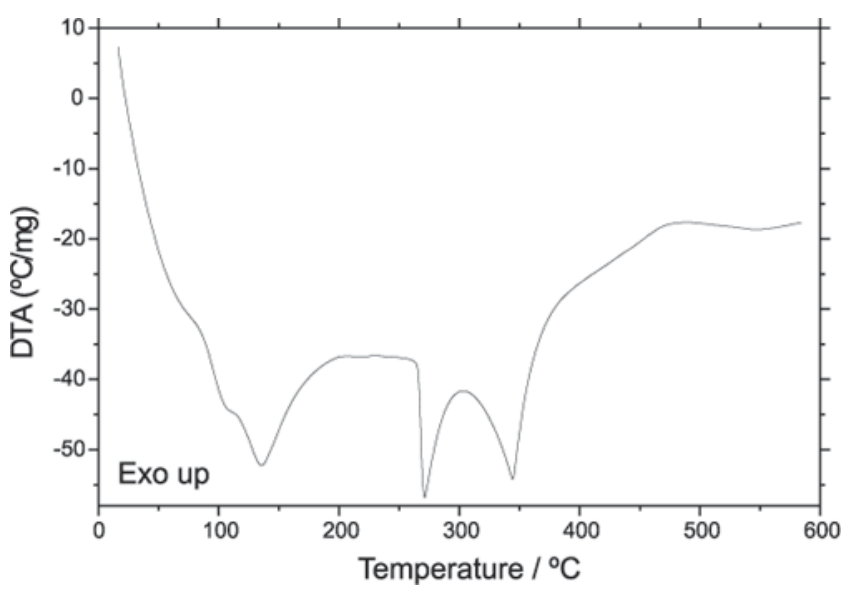

Figure 5 - DTA curve of aminophylline sample $\left(m_{i}=8.607 \mathrm{mg}\right)$.

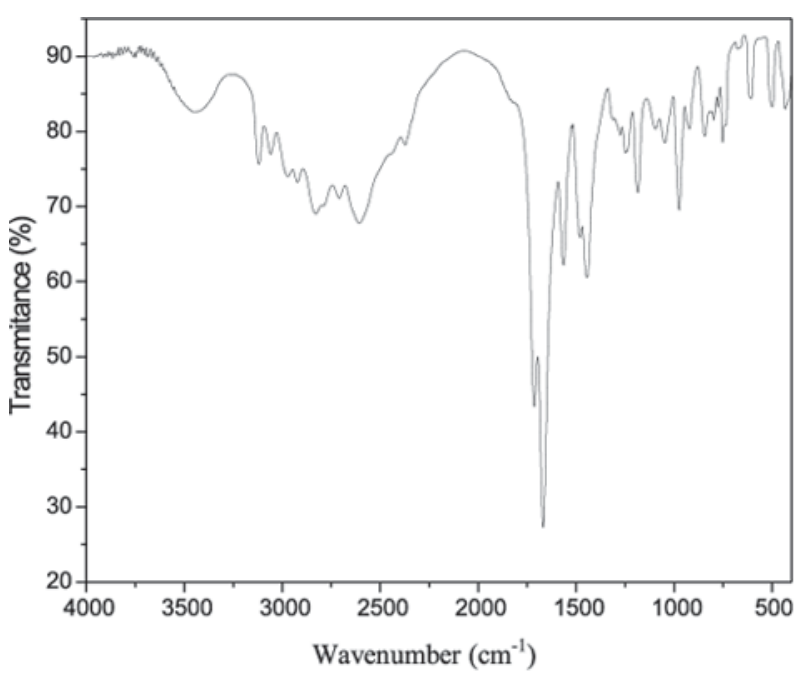

Figure 6 - FTIR spectrum of sample after condensation of aminophylline. 


\section{Caffeine}

The TG and DTG curves of caffeine are shown in Fig. 7. These curves show that the compounds are stable up to $175^{\circ} \mathrm{C}$ and between 175 $315^{\circ} \mathrm{C}$, the total mass loss occurs in a single step.

The DTA curve of caffeine is shown in Fig. 8. The first endothermic peak at $163^{\circ} \mathrm{C}$ is due to a change of crystalline structure in compliance with the X-ray powder patterns, as can be seen in Fig. 9 and in agreement with the literature [10]. The endotherm between $225-320^{\circ} \mathrm{C}$, with two peaks at $270^{\circ} \mathrm{C}$ and $312^{\circ} \mathrm{C}$ are due to fusion and evaporation respectively. The evaporation of caffeine occurs without decomposition, in compliance with the infrared spectra of caffeine and solidified sample collected after evaporation, as can be seen in Fig. 10.

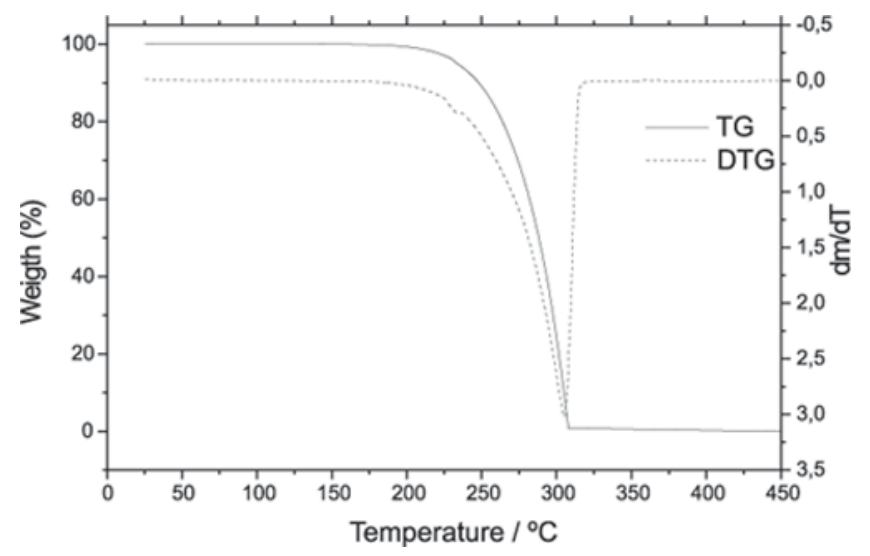

Figure 7 - TG and DTG curves of caffeine sample $\left(\mathrm{m}_{\mathrm{i}}=7.435 \mathrm{mg}\right)$.

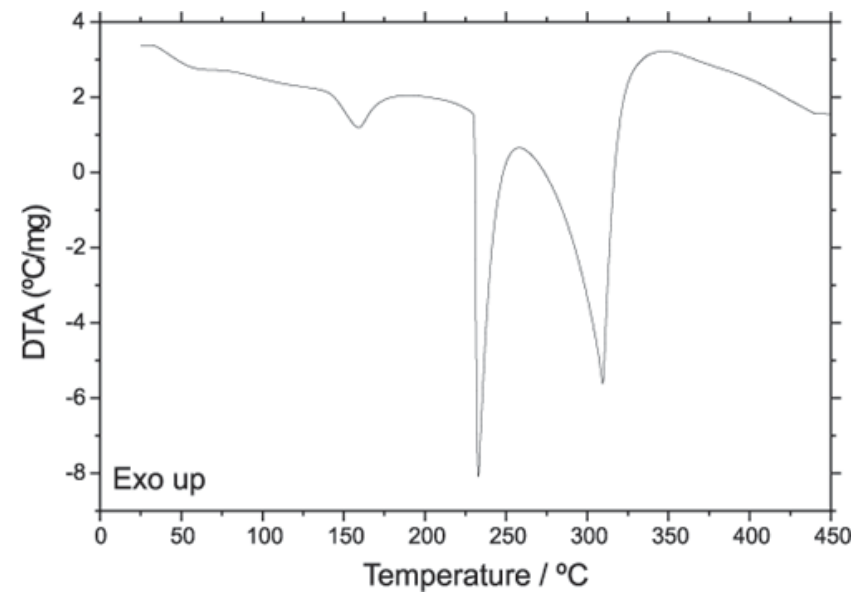

Figure 8 - DTA curve of caffeine sample $\left(m_{i}=7.435 \mathrm{mg}\right)$. 


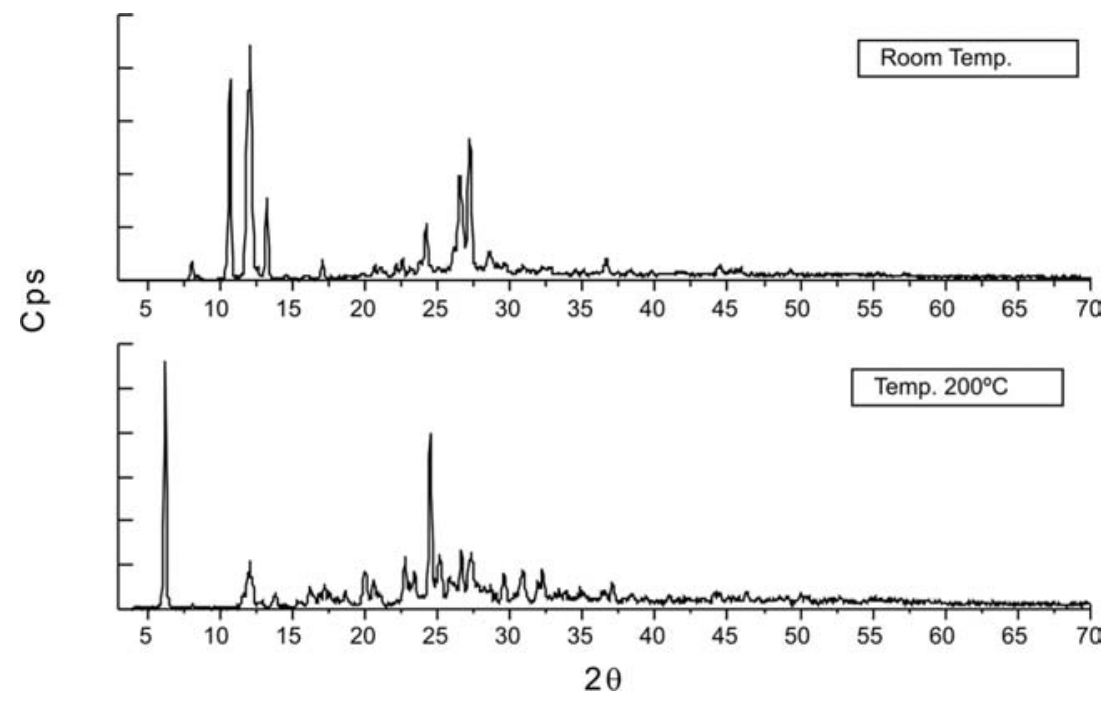

Figure 9 - X-ray diffraction powder patterns of the caffeine sample at room temperature and at $200{ }^{\circ} \mathrm{C}$.
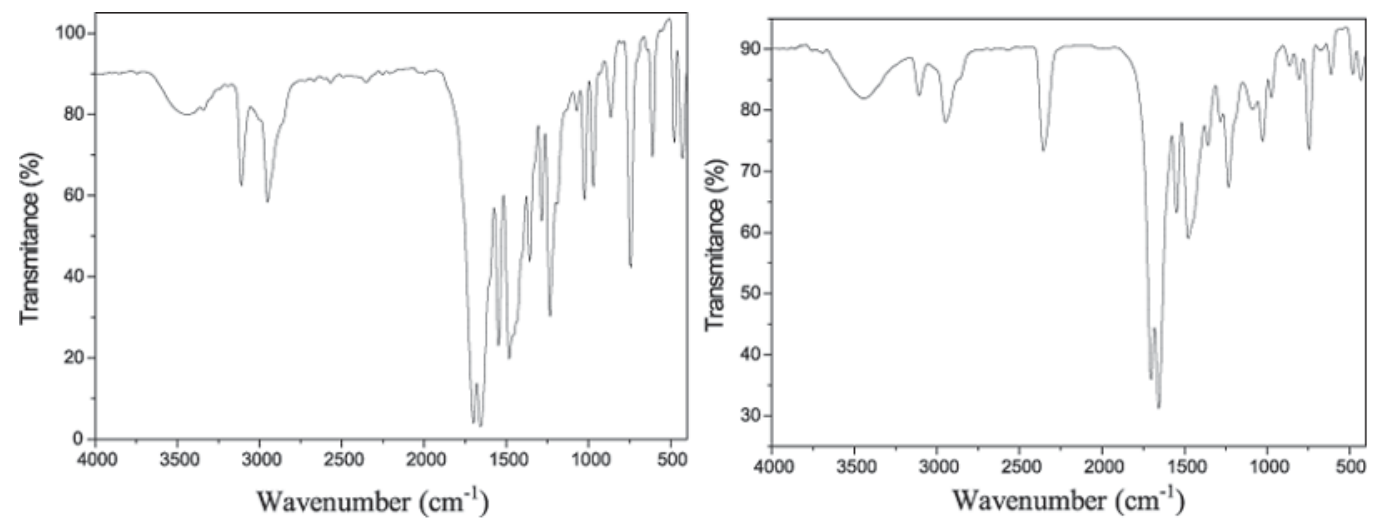

Figure 10 - FTIR spectra of the caffeine (a) sample at room temperature (b) evaporation product.

Uric Acid

The TG and DTG curves of uric acid are shown in Fig. 11, these curves shows that compound is stable up to $375^{\circ} \mathrm{C}$, and above this temperature the mass loss beginning through a fast process up to $480^{\circ} \mathrm{C}$, followed by a slow process between 480 and $600^{\circ} \mathrm{C}$, with loss of $60 \%$ and $29 \%$, respectively. These curves also show that the mass loss is still being observed up to $600^{\circ} \mathrm{C}$.

The DTA curve of uric acid is shown in Fig. 12. The endothermic ascribed to thermal decomposition corresponding to the fast mass loss of the TG and DTG curves. 


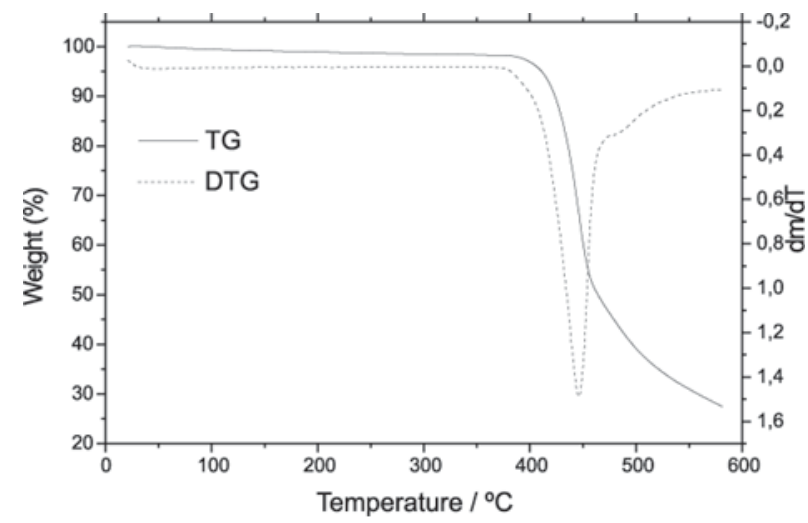

Figure 11 - TG and DTG curves of uric acid sample $\left(m_{i}=7.581 \mathrm{mg}\right)$.

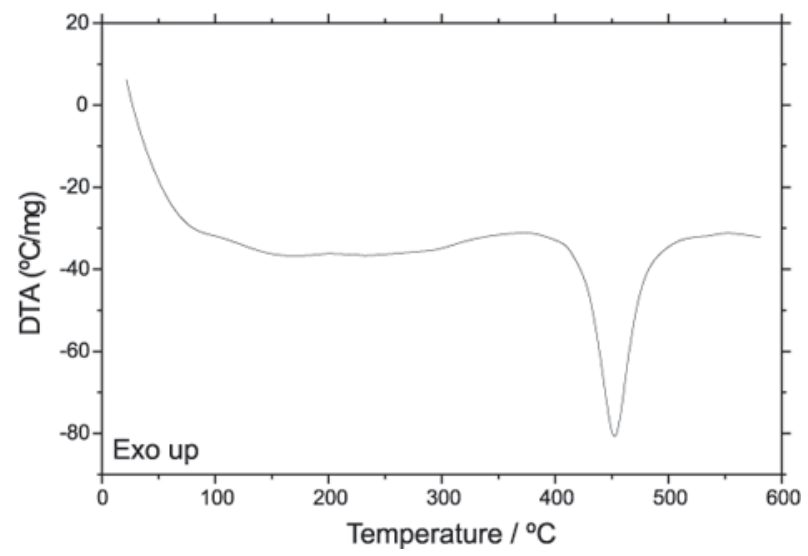

Figure 12 - DTA curve of uric acid sample $\left(m_{i}=7.5809 \mathrm{mg}\right)$.

\section{Conclusion}

The TG, DTG, DTA curves, infrared spectroscopic spectra and X-ray powder patterns, provided information on the thermal stabilities and thermal decomposition of these compounds.

\section{Acknowledgement}

The authors thank FINEP - Brazil (Proc. RC: 312-0023/98) for financial support.

Recebido em: 07/01/04

Aceito em: 16/02/04

E. Schnitzler, M. Kobelnik, G. F. C. Sotelo, G. Bannach, M. Ionashiro. Estudo termoanalítico de compostos derivados da purina.

Resumo: Os métodos térmicos em análises estão sendo atualmente muito utilizados nas investigações cientificas. Neste trabalho a termogravimetria-análise térmica diferencial simultânea (TG-DTA), difratometria de raios X pelo método do pó, espectroscopia de absorção na região do infravermelho foram utilizadas para estudar os compostos derivados da purina. Sendo estes: aminofilina. teofilina, cafeína e ácido úrico. Os resultados forneceram informações com respeito à estabilidade térmica e decomposição térmica sobre esses compostos.

Palavras-chave: aminofilina; teofilina; cafeína; ácido úrico; TG; DTA. 


\section{References}

[1] M. Montagut, L. Codern, J. Carulla, Afinidad 25 (1963) 316. [2] W. W. Wendlandt, L. W. Collins, Anal. Chim. Acta 71 (1974) 411.

[3] G. Margomenou-Leonipoulou, K. Theodoratos, G. G. Macris, Arch. Pharm. 30 (1974) 100.

[4] E. Domagalina, T. Slawik, Acta Pol. Pharm. 33 (1976) 623. [5] A. Chauvet, J. Masse, J. Trav. Sec. Pharm. Montpellier 38 (1978) 31.

[6] A. Rodecki, M. Wesolowski, J. Thermal Anal. 17 (1979) 73. [7] M. Wesolowski, Mikrochim. Acta 1(1980) 199.

[8] M. Wesolowski, Acta Pharm. Iugosl. 32 (1982) 303.

[9] C. Martinez Recari, J. M. Sanches Monge, J. A. Perez de Ciriza, F. Marcótegni, Rev. Asoc. Esp. Farm. Hosp. 6 (1982) 57.

[10] E. Colacio-Rodriguez, J. M. Salas-Peregrin, M. P. SanchezSanchez, A. Mata-Arjona, Thermochim. Acta 66 (1983) 245.

[11] D. J. Ager, K. S. Alexander, A. S. Bhatti, J. S. Blackbum,

D. Dollimore, T. S. Koogan, K. A. Mooseman, G. M. Muhvic,
B. Sims, V. J. Webb, J. Pharm. Sci. 75 (1986) 77.

[12] D. Giron, J. Pharm. Biomed. Anal. 4 (1986) 755.

[13] G. Gupchup, K. Alexander, D. Dollimore, Thermochim. Acta 196 (1992) 279

[14] M. Sh. Lvova, E. I. Kozlov, I. A. Wishnevezkaya, J. Therm. Anal. 40 (1993) 405.

[15] D. Giron, Thermochim. Acta 248 (1995) 1.

[16] M. Epple, H. K. Cammenga, S. M. Sarge, R. Diedrich, V. Balek, Thermochim. Acta 250 (1995) 29.

[17] Y. A. Ribeiro, J. D. S. Oliveira, M. I. G. Leles, S. A. Juiz, M. Ionashiro, J. Therm. Anal. 46 (1996) 1645.

[18] Y. A. Ribeiro, A. C. F. Caíres, N. Baralle, M. Ionashiro, Thermochim. Acta 279 (1996) 177.

[19]E. Schnitzler, M. A. S. Carvalho-Filho, C. C. Stadler, A. M Volpato, M. Ionashiro, Ecl. Quím. 26 (2001) 41.

[20] M. Wesolowski, P. Szynkaruk, J. Therm. Anal. Cal. 65 (2001) 599.

[21] The Merck Index: an encyclopedia of chemicals drugs and biologicals, Merck, Rohway, 11th edn., 1989. 